\title{
Lichen species dominance and the resulting photosynthetic behavior of Sonoran Desert soil crust types (Baja California, Mexico)
}

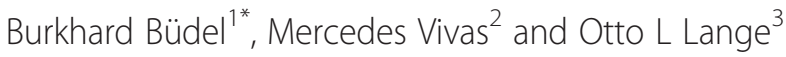

\begin{abstract}
Introduction: Lichen dominated biological soil crusts (BSCs) occur over large areas in the Sonoran Desert of the southwestern USA and northwest Mexico. In Baja California BSCs show a distinct patchiness and several types can be distinguished. Two chlorolichen- and two cyanolichen-dominated BSCs were selected. We hypothesize that patchiness and the resulting domination of certain functional lichen groups will result in patchiness of photosynthetic $\mathrm{CO}_{2}$-uptake related to environmental factors as well.

Methods: Four different soil crust samples were placed in cuvettes and their $\mathrm{CO}_{2}$ exchange was recorded in an open system with an infrared gas analyzer. Air blown over the BSCs had a controlled $\mathrm{CO}_{2}$ content of $350 \mathrm{ppm}$. Four cuvettes were operated in parallel. Photosynthetic $\mathrm{CO}_{2}$ exchange was continually recorded throughout the experiment.

Results: Besides the dominating chlorolichens Psora decipiens and Placidium squamulosum and the cyanolichens Peltula patellata and P. richardsii, several other lichen species and 12 cyanobacterial species were found in the biological soil crusts sampled. The chlorolichen BSCs already gained positive net photosynthesis with high air humidity alone, while the cyanolichen types did not, but showed smaller $\mathrm{CO}_{2}$-uptake depression after water suprasaturation. Such specific net photosynthesis responses to mode of hydration and to crust water content seem to correlate with precipitation characteristics of their habitat.

Conclusions: Species specific photosynthetic performance related to activation of respiration and net photosynthesis as well as to crust water content help to explain niche occupation and species composition of BSCs. Different functional types have to be considered when they have a patchy distribution.
\end{abstract}

Keywords: Biological soil crust, Lichens, Cyanobacteria, Photosynthesis, Reactivation, Sonoran desert

\section{Introduction}

More than 35\% of the Earth's landmass is arid to semiarid and soils of these regions are frequently covered by biological soil crusts, BSCs (Pointing and Belnap 2012). They are intimate associations between soil particles, cyanobacteria, algae, microfungi, lichens and bryophytes (Belnap et al. 2003). In such regions BSCs can have a strong influence on ecosystem functioning. In particular they can improve the stability of soils and the resistance to soil erosion by wind and water increases with BSC development independent of the substrate. BSCs also improve soil fertility and influence hydrological cycles. The

\footnotetext{
* Correspondence: buedel@rhrk.uni-kl.de

'Plant Ecology and Systematics, Biology Department, University of Kaiserslautern, P.O. Box 3049, D-67653, Kaiserslautern, Germany Full list of author information is available at the end of the article
}

effects of various types of BSC have been well studied in arid and semi-arid environments and it is in such nutrient and/or water poor environments that they make their greatest impact (Belnap and Lange 2003). By fixing atmospheric carbon, the photoautotrophic components of the BSC can underpin the trophic hierarchy by leaching some fixed carbon into the soils (Dudley and Lechowicz 1987, Dümig et al. 2013) and by themselves being a food resource for heterotrophs. In addition BSC components like free living cyanobacteria and cyanolichens can also fix atmospheric nitrogen and supply this to the communities. These ecosystem services are of special importance in areas where no higher primary producer influences the simple and nutrient poor soils.

Being composed of different organisms does not necessarily mean that they all contribute equally to 
biomass. Depending on environmental conditions, certain groups of organisms dominate over others, resulting in crusts where most of the biomass is typically either formed by cyanobacteria, by cyano- and/or chlorolichens lichens, or by liverworts or mosses. Although patchiness and pattern formation in time and space of BSCs is a known phenomenon (Belnap et al. 2006), little is known about the factors driving small scale patterns of abundance and distribution (Martinez et al. 2006; Richter et al. 2012). Few studies have dealt with small scale pattern formation of crusts. However, one study revealed a scale-dependent positive correlation between abiotic stress such as water and nutrient availability and co-occurrence of BSC-lichens (Maestre et al. 2009).

Büdel et al. (2009) distinguished between 7 major crust types in their study on South African BSCs. For example BSC-type 4 was defined being a late successional cyanobacterial crust with green algae, cyano- and chlorolichens. However, all crust types showed strong small scale patterns, with different groups of species dominating in certain patches. Soil crust patchiness happens in the scale of square centimeters to square meters and can be a highly dynamic process with time periods in the range of several months for cyanobacteria and algae (Belnap et al. 2006). Since cyanobacteria, cyanolichens, and chlorolichens can vary considerably in photosynthetic properties related to reactivation after desiccation and thallus water content (Lange and Kilian 1985; Lange et al. 1986; 1993), patchiness in species composition most probably also results in considerable patchiness of photosynthetic $\mathrm{CO}_{2}$-fixation rates. In order to test this hypothesis and to quantify its possible impact we studied the $\mathrm{CO}_{2}$-uptake patterns of four differently lichen-dominated BSCs from Baja California (Sonoran Desert) under experimentally controlled condi- tions. The BSC-patches investigated, were each covered by one lichen species only. Two were dominated by the cyanolichens Peltula richardsii or P. patellata, and two by the chlorolichens Psora decipiens or Placidium squamulosum, respectively (see Figure 1).

\section{Methods}

\section{Sampling and collecting sites}

Biological soil crusts (BSCs) dominated by one single lichen species were collected for photosynthesis measurements at four different regions of the Sonoran Desert region of Baja California, Mexico, ranging between $23^{\circ}$ to $28^{\circ}$ latitude north. Average precipitation rates of the four sites differ from 110 to $250 \mathrm{~mm}$ /year. In all cases several species of free living cyanobacteria were present in the samples (see Table 1), but no other lichen or bryophyte. Samples were removed from the soil with a maximum of $8 \mathrm{~mm}$ soil attached to them. After collection the samples were air dried in the field, wrapped in paper and transported back to the laboratory, where they were stored frozen $\left(-20^{\circ} \mathrm{C}\right)$ until used for the experiments. Before the experiments, samples were unfrozen at room temperature $\left(21^{\circ} \mathrm{C}\right)$ and subsequently remoistened to saturation at $21^{\circ} \mathrm{C}$ and low light intensities (ca. 60-100 $\mu \mathrm{mol}$ photons $/ \mathrm{m}^{2}$. sec PAR) for three days (12:12 hours light:dark).

Patchiness of BSCs in Baja California was noticed during 3 field trips in the framework of the lichen flora of the Sonoran Desert project (see Nash et al. 2002, 2004, 2007, Volumes 1-3), covering all regions of Baja California. Patchiness of BSCs in terms of varying lichen species composition was found a regular feature and patches dominated by one species ranged between few square centimeters to a square meter (own unpublished observation).
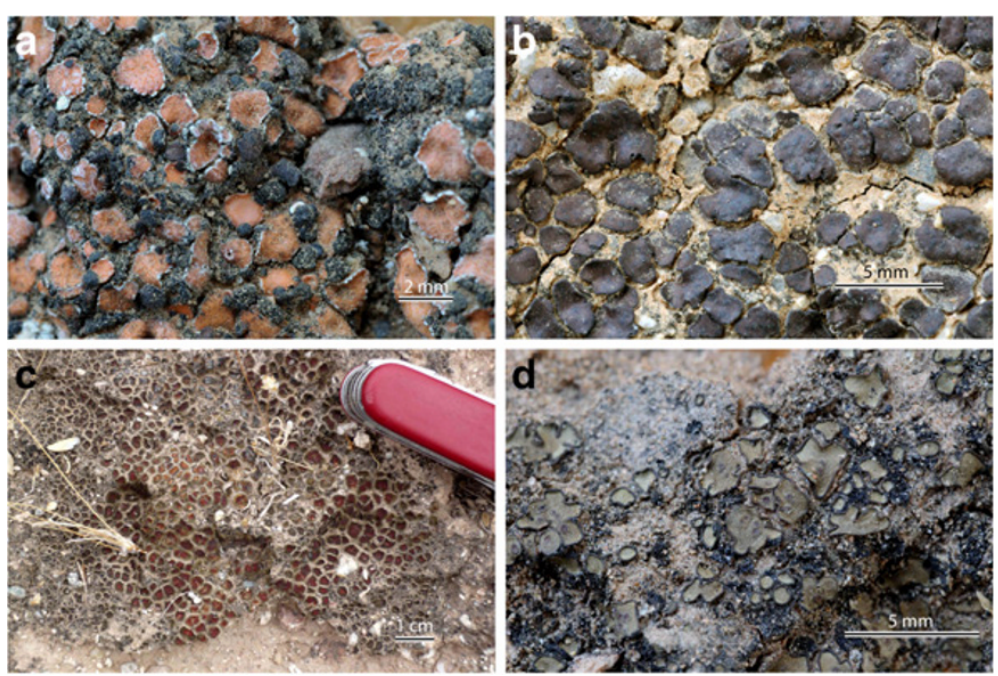

Figure 1 Biological soil crust types with dominating lichen species. a) chlorolichen Psora decipiens; b) chlorolichen Placidium squamulosum; c) cyanolichen Peltula richardsii; d) cyanolichen Peltula patellata. 
Table 1 List of lichens and cyanobacteria determined in the Baja California-Sonoran desert BSC type

\begin{tabular}{|c|c|c|c|c|}
\hline & $\begin{array}{l}\text { A) } 30 \mathrm{~km} \text { South of } \\
\text { Bahia de Los Angeles }\end{array}$ & $\begin{array}{l}\text { B) Near } \\
\text { Todos Santos }\end{array}$ & $\begin{array}{l}\text { C) S of Ciudad } \\
\text { Insurgentes }\end{array}$ & $\begin{array}{l}\text { D) NW of San Ignacio, } \\
\text { Desierto de Vizcaino }\end{array}$ \\
\hline \multicolumn{5}{|l|}{ canobacteria } \\
\hline Borzia trilocularis Cohn ex Gomont & + & & & \\
\hline Chroococcidiopsis sp. & + & + & + & + \\
\hline Gloeocapsa atrata Kützing & & + & & \\
\hline Gloeocapsa kützingiana Nägeli & & + & + & \\
\hline Gloeocapsa punctata Nägeli & & & + & \\
\hline Microcoleus subtorulosus Gomont ex Gomont & & + & + & \\
\hline Nostoc microscopicum Carm. ex Bor. et Flah. & + & + & + & + \\
\hline Phormidium californicum Drouet & + & & + & + \\
\hline Phormidium inundatum Kützing ex Gomont & + & + & & \\
\hline Schizothrix fragilis Kützing ex Gomont & + & + & + & \\
\hline Scytonema ocellatum (Dill.) Lyng. ex Born. et Flah. & + & + & + & + \\
\hline Stigonema hormoides Bornet et Flahault & + & & & \\
\hline \multicolumn{5}{|l|}{ cyanolichens } \\
\hline Collema cf. crispum & & + & + & \\
\hline Heppia adglutinata (Kremp.) A. Massal. & & + & & + \\
\hline Heppia despreauxii (Mont.) Tuck. & + & + & + & \\
\hline Heppia sp. & & & & + \\
\hline Peltula patellata (Bagl.) Swinscow \& Krog & & + & + & $+^{*}$ \\
\hline Peltula richardsii (Herre) Wetmore & & & $t^{*}$ & \\
\hline Pseudopeltula heppioides Henssen & & + & & + \\
\hline \multicolumn{5}{|l|}{ chlorolichens } \\
\hline Placidium squamulosum (Ach.) Breuss & & $+^{*}$ & & \\
\hline Psora decipiens (Hedw.) Hoffm. & $+^{*}$ & & & + \\
\hline Toninia sedifolia (Scop.) Timdal & + & & & \\
\hline Toninia lutosa (Ach.) Timdal & + & & & \\
\hline
\end{tabular}

* indicates dominating species.

Description of the BSC samples and their geographical origin that were used for the $\mathrm{CO}_{2}$-gas exchange measurements:

A) A soil crust piece of $19.4 \mathrm{~cm}^{2}$ dominated by approximately 570 thalli of Psora decipiens (Hedw.) Hoffm. (chl) from calcareous soil, Mexico, Baja California, along route $1,30 \mathrm{~km}$ south of turnoff to Bahia de Los Angeles, ca. 100 m a.s.l., $28^{\circ} 45 \mathrm{~N}$, $114^{\circ} 07^{\prime} \mathrm{W}$, leg B. Büdel, no. 20207a. Average precipitation is $\sim 250 \mathrm{~mm} /$ year commencing from October to April with a peak in January to March. The chlorophyll $a$ of the sample refers to $287.21 \mathrm{mg} / \mathrm{m}^{2}$.

B) $23.1 \mathrm{~cm}^{2}$ BSC dominated by approximately 580 thalli of Placidium squamulosum (Ach.) Breuss (chl), Mexico, Baja California Sur, turnoff to Presa de Santa Cruz at $42 \mathrm{~km}$, post along Hwy 19 to Todos Santos, $180 \mathrm{~m}$ a.s.l., $23^{\circ} 33^{\prime} \mathrm{N}, 110^{\circ} 13^{\prime} \mathrm{W}$, leg. B. Büdel, no. 20152b. Average precipitation is $~ 195 \mathrm{~mm} /$ year commencing from July to December with a peak from August to October. Chlorophyll $a=175.59 \mathrm{mg} / \mathrm{m}^{2}$.

C) $11.5 \mathrm{~cm}^{2}$ BSC dominated by approximately 63 thalli of Peltula richardsii (Herre) Wetmore (cyl) from floodplains on loamy soils with Pachycereus-cacti and Acacia, Mexico, Baja California Sur, $8 \mathrm{~km} \mathrm{~W}$ of Ciudad Constitucion, $\mathrm{S}$ of Ciudad Insurgentes, $20 \mathrm{~m}$ a.s.l., and $25^{\circ} 00^{\prime} \mathrm{N}, 111^{\circ} 43^{\prime} \mathrm{W}$, leg. B. Büdel, no. 20194a. Average precipitation is $\sim 120 \mathrm{~mm}$ /year commencing from July to January with two peaks, one from July to September, the second in December and January. Chlorophyll $a=27.1 \mathrm{mg} / \mathrm{m}^{2}$.

D) $23.1 \mathrm{~cm}^{2}$ BSC dominated by approximately 785 thalli of Peltula patellata (Bagl.) Swinscow \& Krog (cyl) from soil patches between large boulders, Mexico, Baja California Sur, 3,5 km from highway 1 along road to Punta Abreojos, NW of San Ignacio, Desierto de Vizcaino, 300 m a.s.l., $27^{\circ} 15 \mathrm{~N}$, 
$113^{\circ} 11^{\prime} \mathrm{W}$, leg. B. Büdel, no. 20201a. Average precipitation is $\sim 110 \mathrm{~mm} /$ year commencing equally from June to March. Chlorophyll $a=113.5 \mathrm{mg} / \mathrm{m}^{2}$.

\section{Gas-exchange measurements}

Samples of the soil crust were fixed in their natural position in a stainless steel wire basket and positioned in small acryl-glass cuvettes, which were submerged in a water bath for temperature control $\left(15.0 \pm 0.1^{\circ} \mathrm{C}\right.$ in darkness). The $\mathrm{CO}_{2}$ uptake and release of the sample was recorded in an open system with an infrared gas analyzer (BINOS, Rosemount, Hanau, Germany) in the differential mode. For this, air was blown over the BSCs through the cuvettes, the $\mathrm{CO}_{2}$ concentration of which was controlled at $350 \mathrm{ppm}$ by a gas-mixing device that added pure $\mathrm{CO}_{2}$ to $\mathrm{CO}_{2}$-free air by means of mass-flow controllers. Before entering the cuvette, the air was led through a Peltier-operated water-vapor trap that precisely regulates the water vapor concentration. The air dew point was recorded by dew point mirrors before and after the cuvettes. In one cuvette, air humidity was additionally recorded with a humidity sensor (Rotronic Company, Zurich, Switzerland). Four cuvettes were operated in parallel to each other (the measuring system was built by Walz Meß- und Regeltechnik, Effeltrich, Germany). Photosynthetic $\mathrm{CO}_{2}$ uptake and respiratory $\mathrm{CO}_{2}$ release were continually recorded throughout the experiment with an accuracy of \pm 0.15 ppm. Soil crust $\mathrm{CO}_{2}$ exchange was related to surface area. Lichen chlorophyll was determined according to Ronen and Galun (1984).

All of the measurements were standardized as follows (Lange and Kilian 1985): the soil crust material was held for 3 days in a growth chamber at $21^{\circ} \mathrm{C}$ with a regime of $12 \mathrm{~h}$ light:12 $\mathrm{h}$ dark and was sprayed with deionized water once a day. This treatment served to reactivate the biological soil crusts to a standard level of photosynthetic activity (for more details of methods see Lange et al. 1993).

Two types of experiments have been conducted. For the resurrection experiment with high air humidity, the BSCs were dried to a low water content of about 1 to $4 \%$ of their dry weight by placing them in a desiccator over silica gel for 3,5 days. The dry thalli were then transferred to the gas exchange cuvettes where they were treated from the beginning with air of $96 \%$ relative humidity (at $15^{\circ} \mathrm{C}$ ). Great care was taken that water did not condense on the thallus of the lichens at any time during this procedure. The samples in the cuvettes were kept dark with light $(200 \mu \mathrm{mol}$ photons $/ \mathrm{m}^{2} \cdot \mathrm{s}$ PAR) switched on for 15 minutes in intervals of $1-4$ hours for detection of possible $\mathrm{CO}_{2}$-fixation.

After 72 hours of humidity treatment, the enclosed soil crusts reached equilibrium with respect to the water potential of the surrounding air, i.e. their weight (water content) no longer increased. Subsequently (after 72 hours of treatment in the routine experiments), they were sprayed with water. During the following period of alternating light and dark phases and treatment with air of $80 \%$ relative humidity, the gas exchange of the initially saturated soil crusts was monitored while they dried out.

In order to determine the specific water content related photosynthesis of the four different BSC-types, all samples were moistened by spraying them with water until maximal hydration. The four stainless steel wire baskets with the BSC-types were then placed in the measuring chambers and exposed to $200 \mu \mathrm{mol}$ photons $/ \mathrm{sec} \cdot \mathrm{m}^{2}$ photosynthetic active radiation at $15^{\circ} \mathrm{C}$; incoming air humidity was set to $96 \%$ at the beginning of the experiment and later on reduced to $80 \%$. Every few hours (3-15 hours intervals) the samples were measured for their net photosynthesis and dark respiration. Immediately after each measurement, samples were removed from the cuvettes and their weight was determined in order to calculate the decrease of the BSC water content. This process was continued for 97 hours with each BSC-sample until cease of any $\mathrm{CO}_{2}$ exchange due to total drying.

\section{Results}

In addition to the dominating lichen species Psora decipiens, Placidium squamulosum, Peltula patellata and $P$. richardsii, several other lichen species and 12 free living cyanobacterial species were found at the four BSC collection sites in Baja California. For a complete cyanobacterial and lichen species inventory see Table 1 . The experimental material (Figure 1) contained one lichen species only, but was accompanied by free living cyanobacteria (Table 1 ) on top of the soil between lichen thalli. Their coverage of the total sample area was always less than $2 \%$. While the two chlorolichen-dominated BSCs came from sites with an annual precipitation of 190 and $250 \mathrm{~mm}$, precipitation of the two cyanolichen dominated BSCs sampling sites is roughly half as much, 110 and $120 \mathrm{~mm}$.

Reactivation of the initially dry Psora decipiens (chl) dominated BSC (Figure 1a) became measureable 3 hours after exposure to high air humidity for dark respiration (R) and after 9.5 hours for net photosynthesis (NP). After about 60 hours and through water vapor hydration alone, the lichen attained ca. $37.5 \%$ of its maximal $\mathrm{CO}_{2}$ uptake that was enabled after subsequent moistening of the thalli with liquid water (Figure 2). In a repeat of the reactivation experiment, spraying with water after 72 hour exposure to high air humidity resulted in a water suprasaturation of the crust. As a consequence, the NP curve dropped (Figure 2), and recovered higher $\mathrm{CO}_{2}$ uptake rates by evaporative water loss for a few hours. In the second run of experiments with drying-down curves after maximal water saturation of the samples, dependence of $\mathrm{CO}_{2}$ exchange on crust hydration has been quantified (Figure 3). Maximum rates of NP $(90-100 \%$ of those gained in the second experiment) were reached at crust water content 

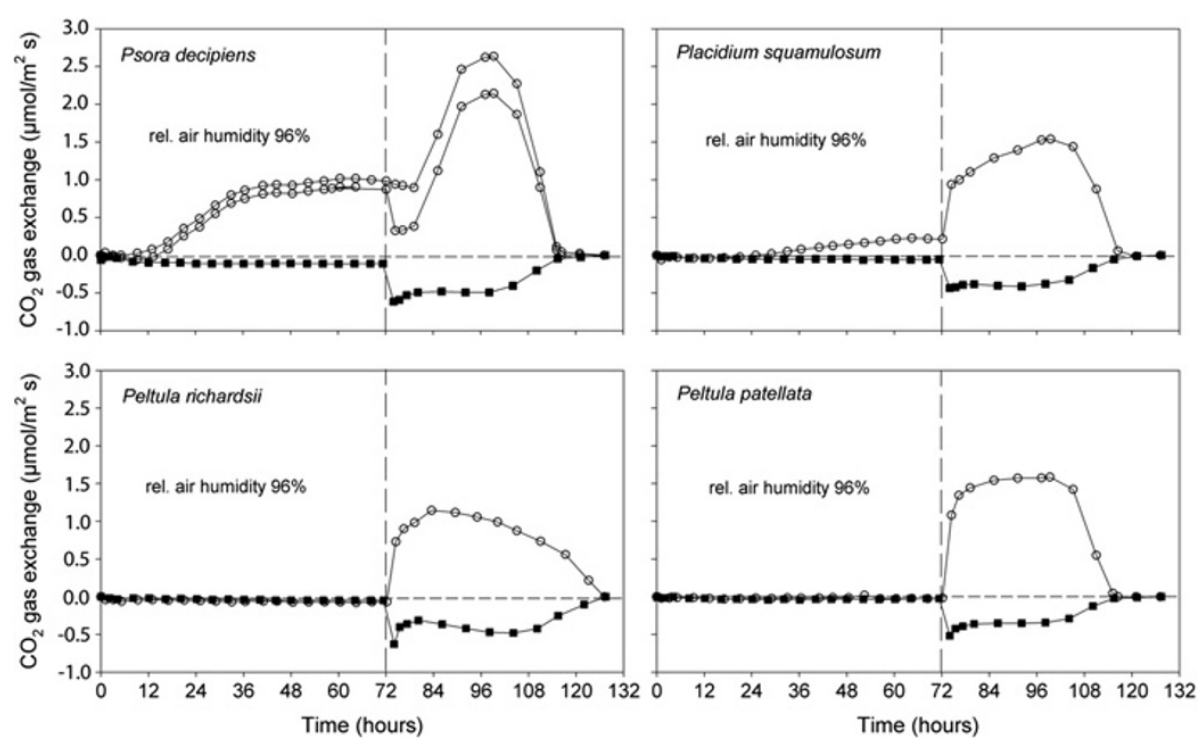

Figure 2 Four BSC samples with one dominating and indicated species each. Reactivation of net photosynthesis (open circles) and dark respiration (black squares) by high air humidity (related to surface area). Dry crusts were exposed to air with a relative humidity of $96 \%$ for 72 hours at $15^{\circ} \mathrm{C}$ in darkness with short cycles of illumination with $200 \mu \mathrm{mol}$ photons $/ \mathrm{m}^{2}$. s PAR. After 72 hours, samples were sprayed with water to saturation (vertical line) and then kept at $80 \%$ declining to $60 \%$ rel. air humidity until $\mathrm{CO}_{2}$ exchange completely ceased with dehydration.

in the range between 0.38 and $0.81 \mathrm{~mm}$ precipitation equivalent. At higher degrees of hydration, a strong suprasaturation depression of $\mathrm{CO}_{2}$ uptake became obvious that reduced NP to $9.7 \%$ of its maximal rate in the same experiment (Figure 3).

The initially dry Placidium squamulosum (chl) dominated crust (Figure 1b) showed first reactions of $R$
4 hours 30 minutes after exposure to high air humidity alone. Net photosynthesis started 24 hours after exposure and reached $14.7 \%$ of its maximal $\mathrm{CO}_{2}$-uptake after subsequent moistening with liquid water (Figure 2). In the second experiments, the drying down curves after maximal water saturation of the crust, maximum rates (90-100\%) of NP were determined at crust water content
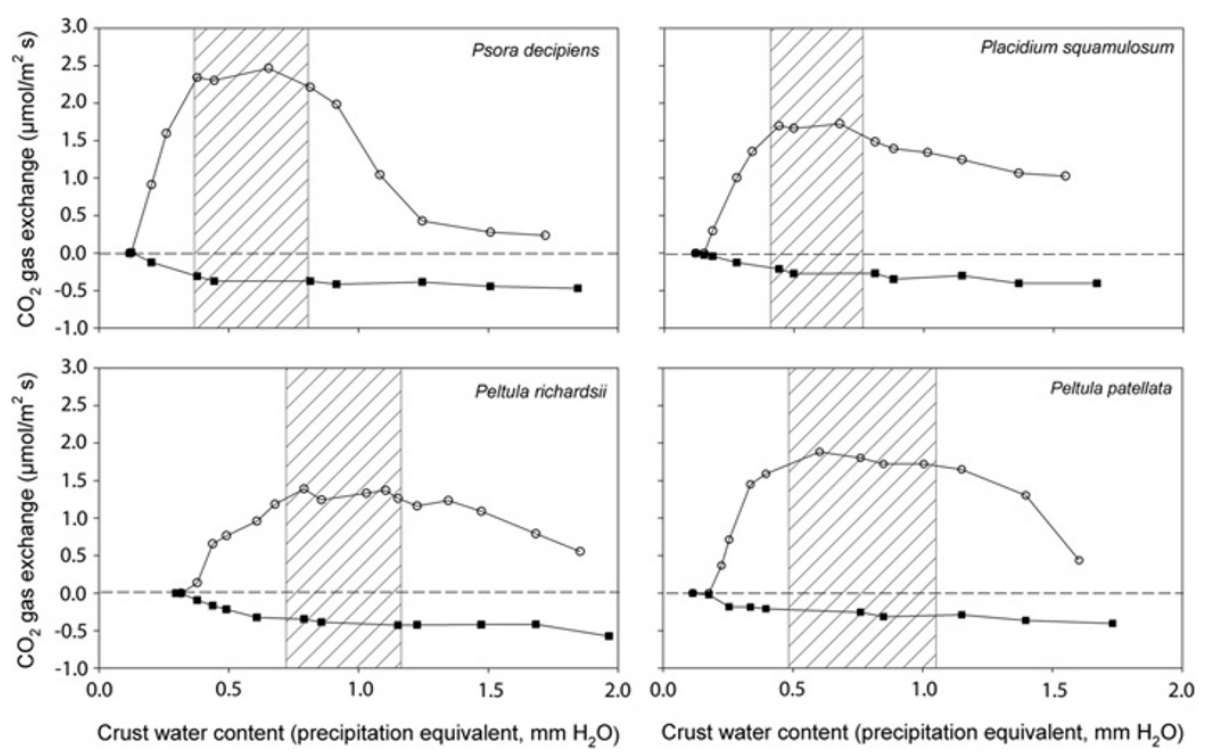

Figure 3 Four BSC samples with one dominating and indicated species each. Net photosynthesis (open circles) and dark respiration (black squares; related to surface area) versus thallus water content (expressed as equivalent to $\mathrm{mm} \mathrm{H}_{2} \mathrm{O}$ precipitation). Initially fully water soaked samples were measured until $\mathrm{CO}_{2}$ exchange completely ceased with dehydration. Hatched area indicates range of water content at which $90 \%$ of the maximum net photosynthesis is attained. Experimental conditions: rel. air humidity $80 \%, 200 \mu \mathrm{mol}$ photons $/ \mathrm{m}^{2} \cdot \mathrm{s}$ PAR, temperature: $15^{\circ} \mathrm{C}$. 
between 0.40 to $0.77 \mathrm{~mm}$ precipitation equivalents. At higher degrees of hydration, a moderate suprasaturation depression of $\mathrm{CO}_{2}$ uptake appeared, that reduced NP to $59.5 \%$ of its maximum rates in the same experiment (Figure 3).

The initially dry Peltula richardsii (cyl) dominated crust (Figure 1c) did not show any reaction of R and NP to 72 hours exposure with high air humidity alone (Figure 2). Respiration and NP were only activated by spraying with water after 72 hours exposure to high air humidty (Figure 2). Testing the relation of $\mathrm{CO}_{2}$ uptake depending on crust water content in the second experimental setup, these crust type reached maximal $\mathrm{CO}_{2}$ uptake (90-100\%) in a range of 0.72 to $1.17 \mathrm{~mm}$ precipitation equivalent. Higher degrees of hydration resulted in a moderate suprasaturation depression of $\mathrm{CO}_{2}$ uptake, reducing NP to $40.3 \%$ of its maximal rates (Figure 3 ).

For the initially dry $P$. patellata (cyl) dominated crust (Figure 1d), neither reactivation of $\mathrm{R}$, nor activation of NP was observed after exposure to high air humidity alone for 72 hours. Respiration and NP were only reactivated after spraying with liquid water (Figure 2). The second experimental setup revealed with 0.48 to $1.05 \mathrm{~mm}$ precipitation equivalent the widest range of crust water content, at which maximal (90-100\%) $\mathrm{CO}_{2}$ uptake was gained. Higher crust water content resulted in a strong suprasaturation depression of $\mathrm{CO}_{2}$ uptake, which reduced NP to $23.4 \%$ of its maximal rates (Figure 3 ).

\section{Discussion}

The BSCs investigated here all belong to the late successional phase, referring to BSC type 4 (cyanobacterial crust with cyano- and chlorolichens) described by (Büdel et al. 2009) from southwest Africa. The species list given in Table 1 is not representative for the Baja Californian BSCs, as it only lists species found in the samples that were used for the experiments presented here. From own observations and literature we know, that much more lichen-, liverwort-, moss-, cyanobacterial-, and algal-species occur (Flechtner et al. 1998; Rosentreter and Belnap 2003; McCune and Rosentreter 2007). In the present work we focused on the patchiness of photosynthetic performance related to patchiness of dominating lichens species in BSCs at different sites. While $\mathrm{R}$ and NP of the two BSC types dominated by cyanolichens could not be activated by high air humidity alone, the two chlorolichen dominated crust types both recovered $\mathrm{R}$ and NP at different rates. With high relative air humidity (96\%), the Psora decipiens crust reached almost $38 \%$ and the Placidium squamulosum crust roughly $15 \%$ of their referring maximum rates attained after hydration with liquid water. This is well in accordance with the findings of (Lange and Kilian 1985) and (Lange et al. 1993), who first showed that, in contrast to chlorolichens, cyanolichens of different taxonomical groups cannot be activated with high air humidity alone. The large difference between maximum rates reached and the time for reactivation of NP between the two species (Figure 2, upper graphs) suggest an advantage for Psora decipiens in habitats that regularly experience high air humidity as for example near the coastline.

Experimental results about photosynthetic properties of BSC lichens are available for a small selection of taxa only. The photosynthetic rates found in the four lichen dominated BSC samples investigated here, were well in accordance with those from other geographical regions (Table 2). From hot arid southern Utah (USA), the BSC-related lichens Diploschistes diacapsis (Ach.) Lumbsch (chl), Psora cerebriformis W. Weber (chl), and Squamarina lentigera (Weber) Poelt (chl), were analyzed as individual species (not in the crust) for their $\mathrm{CO}_{2}$ exchange characteristics. Reactivation by high air humidity alone was not tested, but all lichens were activated by extremely small amounts of precipitation $(0.05-0.27 \mathrm{~mm})$. Like the Psora decipiens dominated crust in our investigation, where $\mathrm{CO}_{2}$-uptake was reduced to about $10 \%$ of maximum rates, the lichen P. cerebriformis from Utah, too showed a strong depression when suprasaturated with water. Diploschistes diacapsis only showed slight depression at suprasaturation (Lange et al. 1997). Photosynthetic performance of the gelatinous cyanolichen Collema tenax (Swarz) Ach. em. Degel. from southern Utah was activated at a precipitation equivalent of about $0.1 \mathrm{~mm}$ and had a strong depression in $\mathrm{CO}_{2}$ uptake at values above $1.5 \mathrm{~mm}$ with a maximum $\mathrm{NP}$ peak at $1.00 \mathrm{~mm}$ (Lange et al. 1998). The two cyanolichen dominated BSC samples in our study had comparable values for activation of NP, the depression of $\mathrm{CO}_{2}$ uptake, and the range of water content at which maximum NP (>90\%) is performed (Figure 3). However, maximum photosynthetic rates of both the Peltula richardsii and $P$. patellata dominated samples were roughly half of that found in Collema tenax at higher light intensities (Lange et al. 1998, see also Table 2).

Studies on the photosynthetic performance of lichens as components of BSCs from temperate regions (Germany) included the species Peltigera rufescens (Weiss) Humb. (cyl), Fulgensia fulgens (Swarz) Elenk. (chl), Diploschistes muscorum (Scop.) R. Sant. (chl), Collema tenax, C. cristatum (L.) Weber (cyl), Cladonia convoluta (Lamb) P. Cout. (chl), C. rangiformis Hoffm. (chl), and Squamarina lentigera (Hahn et al. 1989; Lange 2000a; Lange and Green 2003, 2004). In all of these studies diurnal courses of photosynthesis under natural conditions, photosynthetic performance at different light intensities, and water content of individual species (separated from other BSC organisms) were investigated (Table 2). It was shown that all chlorolichens investigated like for example Cladonia convoluta could be activated by early morning dewfall. 
Table 2 Compilation of maximal net $\mathrm{CO}_{2}$-fixation rates of $\mathrm{BSC}$-lichens and lichen dominated $\mathrm{BSCs}$ of different geographical origin (PAR 200-500 $\mu \mathrm{mol} / \mathrm{m}^{2} \cdot \mathrm{s}$; temperature $15-22^{\circ} \mathrm{C}$ )

\begin{tabular}{|c|c|c|c|}
\hline BSC/lichen species & Origin of sample & $\begin{array}{c}\text { Maximal net } \mathrm{CO}_{2} \text {-fixation } \\
\mu \mathrm{mol} \mathrm{CO} \mathrm{CO}_{2} / \mathrm{m}^{2} \cdot \mathrm{s} \\
{\left[\mathrm{nmol} \mathrm{CO} \mathrm{CO}_{2} / \mathrm{mg}(\mathrm{Chla}) \cdot \mathrm{s}\right]}\end{array}$ & Source \\
\hline Acarospora schleicheri & Namib Desert, Namibia & $2.4[10.0]$ & Lange et al. 1994 \\
\hline BSC, Peltula patellata & Baja California, Mexico & $1.9[16.7]$ & this study \\
\hline BSC, Peltula richardsii & Baja California, Mexico & $1.4[51.3]$ & this study \\
\hline BSC, Psora decipiens & Baja California, Mexico & $2.6[8.6]$ & this study \\
\hline BSC, Placidium squamulosum & Baja California, Mexico & $1.7[16.8]$ & this study \\
\hline Caloplaca volkii & Namib Desert, Namibia & $3.3[7.3]$ & Lange et al. 1994 \\
\hline Cladonia convoluta & central Germany & $5.1[19.4]$ & Lange and Green 2003 \\
\hline Collema cristatum & central Germany & $4.6[64.0]$ & Lange 2000b \\
\hline Collema tenax & southern Utah, USA & $5.3[59.0]$ & Lange et al. 1998 \\
\hline Diploschistes diacapsis & southern Utah, USA & $5.0[19.0]$ & Lange et al. 1997 \\
\hline Diploschistes muscorum & central Germany & $5.8[9.1]$ & Lange et al. 1995 \\
\hline Diploschistes scruposus & central Germany & 6.9 & Lange et al. 1999 \\
\hline Fulgensia fulgens & central Germany & $5.2[11.9]$ & Lange et al. 1995 \\
\hline Lecidella cristallina & Namib Desert, Namibia & $4.3[8.8]$ & Lange et al. 1994 \\
\hline Psora cerebriformis & southern Utah, USA & $2.6[9.3]$ & Lange et al. 1997 \\
\hline Peltigera rufescens & central Germany & 4.0 [19.9] & Colesie et al. 2011 \\
\hline Squamarina lentigera & southern Utah, USA & $5.2[21.1]$ & Lange et al. 1997 \\
\hline Squamarina lentigera & central Germany & $4.8[14]$ & Lange et al. 1995 \\
\hline Toninia sedifolia & central Germany & $2.6[4.1]$ & Lange et al. 1995 \\
\hline
\end{tabular}

However, for the cyanolichen Collema cristatum in the same habitat at the same time, this event was just enough to reactivate respiration (Lange 2000b). The Psora decipiens and Placidium squamulosum crusts reached maximum NP rates at lower water content $(0.3$ and $0.44 \mathrm{~mm}$ precipitation equivalent) than the Peltula richardsii crust $(0.72 \mathrm{~mm})$, while $P$. patellata $(0.48 \mathrm{~mm})$ was more or less similar with the Placidium squamulosum crust.

The relation of high thallus water content and photosynthesis was investigated in the BSC lichens Cladonia convoluta, C. pocillum (Ach.) O.J. Richter (chl), Diploschistes muscorum, Squamarina lentigera, Collema tenax, Toninia sedifolia (Scop.) Timdal (chl), and Fulgensia fulgens from steppe vegetation in Germany (Lange et al. 1995). In this study four different response types to water suprasaturation were found: type A lichens (Cladonia convoluta, Diploschistes muscorum) with no or almost no CO2-uptake depression, type B lichens (Squamarina lentigera) with only a little depression, type $\mathrm{C}$ lichens (Collema tenax, Toninia sedifolia) with a large and increasing depression as the water content increases, and finally the type D lichens (Cladonia pocillum, Fulgensia fulgens) with a strong depression but an inflection so that NP is low but constant. According to this classification, the Psora decipiens and probably the Placidium squamulosum dominated BSCs from our study behave like type D lichens (Figure 3), while the Peltula richardsii and P. patellata dominated BSC types refer to type $C$.

Using the BSC green algal lichens Diploschistes muscorum and Fulgensia fulgens from a temperate steppe formation, together with the lithophilic D. scruposus (Schreber) Norm. (chl), (Lange et al. 1999) investigated the response of photosynthesis to external $\mathrm{CO}_{2}$ concentration in interaction with the thallus water content. They showed that indeed a water suprasaturation-induced increase in thallus conductance is responsible for $\mathrm{CO}_{2}$-uptake depression. When exposed to stepwise elevated external $\mathrm{CO}_{2}$ concentrations, the effect of $\mathrm{CO}_{2}$-uptake depression was alleviated, and it eventually disappeared totally (with Fulgensia fulgens at $4500 \mathrm{ppm} \mathrm{CO}_{2}$, Diploschistes muscorum 1000 ppm, D. scruposus 1500 ppm). This clearly shows that species composition of BSC lichens and therefore their productivity might not only be influenced by temperature as a consequence of global warming, but also and probably to an even larger degree, by increasing ambient air $\mathrm{CO}_{2}$ concentrations.

Our results show that patchiness of BSC composition (i.e. dominance of single species) is reflected also in patchiness of photosynthetic performance, a phenomenon which seems to be especially important if different 
functional types of BSC components are involved. This fact might help to interpret soil-crust performance. Thus, as an example, functional patchiness might be part of an explanation for observed differences of soil nutrient availability (soil organic carbon and total nitrogen), that was observed to be significantly different among three desertified grasslands along a degradation gradient, or for the spatial heterogeneity of soil nutrients and respiration of BSC cover in Inner Mongolia (Yu-Chun et al. 2010).

Eldridge and Ferris (1999) reported that the phylogenetic and morphologically closely to Psora decipiens related lichen Psora crenata (Taylor) Reinke (chl), a common BSC component in the Americas and Australia, needs years if not tens of years after disturbance to recover in Australia. Given the important ecological role of BSCs in dry lands of the Earth, also with regard to $\mathrm{CO}_{2}$-fixation (Elbert et al. 2012), detailed knowledge about the mechanisms determining species composition and BSC development in a spatiotemporal scale, is inevitable.

\section{Conclusion}

While the Psora decipiens dominated BSC might have an advantage in habitats with frequent high air humidity (e.g. along the coastline), the cyanolichen dominated BSC-types (Peltula patellata, P. richardsii) might have advantage in dryer sites that are subject to floodings. Placidium squamulosum dominated BSCs are somehow in-between, as they can reactivate NP at least to a small proportion, but, to a lesser degree, also can stand water suprasaturation. However, these theoretical conclusions have to remain speculative and are meant as working hypotheses for continuation of research. As a consequence of our studies, it becomes obvious that investigating photosynthetic carbon gain of BSCs cannot just be performed on small soil crust samples of few square centimeters, but need to cover the full spectrum of BSC patches dominated by different species and species composition.

\section{Abbreviations}

BSC: Biological soil crust; Chl: Chlorolichen; Cyl: Cyanolichen; NP: Net photosynthesis; R: Dark respiration; PAR: Photosynthetic active radiation (400 - 700 nm).

\section{Competing interests}

The authors declare that they have no competing interest.

\section{Authors' contributions}

$\mathrm{OL}$ and $\mathrm{BB}$ designed the study and performed the experiments. MV supported determination of cyanobacteria. All authors read and approved the final manuscript.

\section{Acknowledgements}

We express our sincere thanks to Ellen Kilian ( + ) and Hans Reichenberger for technical support. Thomas H. Nash III is thanked for excellent logistics and support during the field trip to Baja California.

\section{Author details}

${ }^{1}$ Plant Ecology and Systematics, Biology Department, University of Kaiserslautern, P.O. Box 3049, D-67653, Kaiserslautern, Germany. ${ }^{2}$ Department of Plant Science, Faculty of Pharmacy, Universidad Complutense de Madrid,
Plaza Ramón y Cajal, 28040, Madrid, Spain. ${ }^{3}$ Julius-von-Sachs-Institut für Biowissenschaften, University of Würzburg, Julius-von-Sachs-Platz 3, D-97082, Würzburg, Germany.

Received: 29 January 2013 Accepted: 21 March 2013

Published: 26 March 2013

\section{References}

Belnap J, Lange OL (2003) Biological soil crusts: structure, function, and management. Ecological Studies, vol 150, 2nd edition. Springer, Berlin, Heidelberg

Belnap J, Büdel B, Lange OL (2003) Biological Soil Crusts: Characteristics and Distribution. In: Belnap J, Lange OL (ed) Biological soil crusts: structure, function, and management. Ecological Studies, vol 150, 2nd edition. Springer, Berlin, Heidelberg, pp 3-30

Belnap J, Phillips SL, Troxler T (2006) Soil lichen and moss cover and species richness can be highly dynamic: The effects of invasion by the annual exotic grass Bromus tectorum, precipitation, and temperature on biological soil crusts in SE Utah. Appl Soil Ecol 32:63-76

Büdel B, Darienko T, Deutschewitz K, Dojani S, Friedl T, Mohr Kl, Salisch M, Reisser W, Weber B (2009) Southern african biological soil crusts are ubiquitous and highly diverse in drylands, being restricted by rainfall frequency. Microb Ecol 57:229-247

Colesie C, Scheu S, Green TGA, Weber B, Wirth R, Büdel B (2011) The advantage of growing on moss: facilitative effects on photosynthetic performance and growth in the cyanobacterial lichen Peltigera rufescens. Oecologia 169:599-607

Dudley SA, Lechowicz MJ (1987) Losses of polyol through leaching in subarctic lichens. Plant Physiol 83:813-815

Dümig A, Veste M, Hagedorn F, Fischer T, Lange P, Spröte R, Kögel-Knaber I (2013) Biological soil crusts on initial soils: organic carbon dynamics and chemistry under temperate climatic conditions. Biogeosciences Discuss 10:851-894

Elbert W, Weber B, Burrows S, Steinkamp J, Büdel B, Andrae MO, Pöschl U (2012) Contribution of cryptogamic covers to the global cycles of carbon and nitrogen. Nat Geosci 5:459-462

Eldridge DJ, Ferris JM (1999) Recovery of populations of the soil lichen Psora crenata after disturbance in arid South Australia. Rangel J 21:194-198

Flechtner VR, Johansen JR, Clark WH (1998) Algal composition of microbiotic crusts from the central desert of Baja California, Mexico. Great Basin Nat 58:295-311

Hahn SC, Speer D, Meyer A, Lange OL (1989) Photosynthetische Primärproduktion von epigäischen Flechten im "Mainfränkischen Trockenrasen". I. Tagesläufe von Mikroklima, Wassergehalt und $\mathrm{CO}_{2}$ Gaswechsel zu den verschiedenen Jahreszeiten. Flora 182:313-339

Lange OL (2000a) Die Lebensbedingungen von Bodenkrusten-Organismen: Tagesverlauf der Photosynthese einheimischer Erdflechten. Hoppea 61:423-443

Lange OL (2000b) Photosynthetic performance of a gelatinous lichen under temperate habitat conditions: long-term monitoring of $\mathrm{CO}_{2}$ exchange of Collema cristatum. Bibl Lichenol 75:307-332

Lange OL, Belnap J, Reichenberger H (1998) Photosynthesis of the cyanobacterial soil crust lichen Collema tenax from arid lands in southern Utah, USA: role of water content on light and temperature response of $\mathrm{CO}_{2}$ exchange. Funct Ecol 12:195-202

Lange OL, Belnap J, Reichenberger H, Meyer A (1997) Photosynthesis of green algal soil crust lichens from arid lands in southern Utah, USA: role of water content on light and temperature responses of $\mathrm{CO}_{2}$ exchange. Flora 192:1-15

Lange OL, Büdel B, Meyer A, Kilian E (1993) Further evidence that activation of net photosynthesis by dry cyanobacterial lichens requires liquid water. Lichenologist 25:175-189

Lange OL, Green TGA (2003) Photosynthetic performance of a foliose lichen of biological soil-crust communities: long-term monitoring of the $\mathrm{CO}_{2}$ exchange of Cladonia convoluta under temperate habitat conditions. Bibl Lichenol 86:257-280

Lange OL, Green TGA (2004) Photosynthetic performance of the squamulose soilcrust lichen Squamarina lentigera: laboratory measurements and long-term monitoring of $\mathrm{CO}_{2}$ exchange in the field. Bibl Lichenol 88:363-390

Lange OL, Green TGA, Reichenberger H (1999) The response of lichen photosynthesis to external $\mathrm{CO}_{2}$ concentration and its interaction with thallus water-status. J Plant Physiol 154:157-166

Lange OL, Kilian E (1985) Reaktivierung der photosynthese trockener flechten durch wasserdampfaufnahme aus dem luftraum: artspezifisch unterschiedliches verhalten. Flora 176:7-23 
Lange OL, Kilian E, Ziegler H (1986) Water vapor uptake and photosynthesis of lichens: performance differences in species with green and blue-green algae as phycobionts. Oecologia 71:104-110

Lange OL, Reichenberger H, Meyer A (1995) High Thallus Water Content and Photosynthetic $\mathrm{CO}_{2}$ Exchange of Lichens. In: Daniels FJA, Schulz M, Peine J (ed) Contribution to lichenology in honour of Gerhard Follmann. Geobotanical and Phytotaxonomical Study Group. Bot. Inst. University of Cologne, Cologne, pp 139-153

Lange OL, Zellner H, Heber U (1994) Photosynthesis and water relations of lichen soil crusts: field measurements in the coastal fog zone of the Namib Desert. Funct Ecol 8:253-264

Maestre FT, Martinez I, Escolar C, Escudero A (2009) On the relationship between abiotic stress and co-occurrence patterns: an assessment at the community level using soil lichen communities and multiple stress gradients. Oikos 118:1015-1022

Martinez I, Escudero A, Maestre FT, de la Cruz A, Guerrero C, Rubio A (2006) Small-scale patterns of abundance of mosses and lichens forming biological soil crusts in two semi-arid gypsum environments. Aust J Bot 54:339-348

McCune B, Rosentreter R (2007) Biotic soil crust lichens of the Columbia Basin, 1st edition. Northwest Lichenologists, Corvallis, Oregon

Nash TH, III, Ryan BD, Gries C, Bungartz F (2002) Lichen Flora of the Greater Sonoran Desert Region. Lichens Unlimited, Tempe, AZ

Nash TH, III, Ryan BD, Gries C, Bungartz F (2007) Lichen Flora of the Greater Sonoran Desert Region Vol III. Lichens Unlimited, Tempe, AZ

Nash TH, III, Ryan BD, Diederich P, Gries C, Bungartz F (2004) Lichen Flora of the Greater Sonoran Desert Region, vol II. Tempe, AZ, Lichen Unlimited

Pointing SB, Belnap J (2012) Microbial colonization and controls in dryland systems. Nat Rev Microbiol 10:551-562

Richter R, Anchassi D, El-Assad I, El-Matbouly M, Ali F, Makki I, Metcalf JS (2012) Variation in the coverage of biological soil crusts in the State Qatar. J Arid Environ 78:187-190

Ronen R, Galun M (1984) Pigment extraction from lichens with dimethyl sulfoxide (DMSO) and estimation of chlorophyll degradation. Environ Exper Bot 24:239-245

Rosentreter R, Belnap J (2003) Biological soil crusts of North America. In: Belnap J, Lange OL (ed) Biological soil crusts: Structure, function, and management. Ecological Studies, vol 150, 2nd edition. Springer, Berlin, Heidelberg, pp 31-50

Yu-Chun Q, Yun-She D, Zhao J, Qin P, Sheng-Sheng X, Ya-Ting H (2010) Spatial heterogeneity of soil nutrients and respiration in the desertified grasslands of Inner Mongolia, China. Pedosphere 20:655-665

doi:10.1186/2192-1709-2-6

Cite this article as: Büdel et al.: Lichen species dominance and the resulting photosynthetic behavior of Sonoran Desert soil crust types (Baja California, Mexico). Ecological Processes 2013 2:6.

\section{Submit your manuscript to a SpringerOpen ${ }^{\circ}$ journal and benefit from:}

- Convenient online submission

- Rigorous peer review

- Immediate publication on acceptance

- Open access: articles freely available online

- High visibility within the field

- Retaining the copyright to your article

Submit your next manuscript at $>$ springeropen.com 